\title{
A Study of Quality Living Environment for Temporary Construction Workers' Accommodation in Malaysia
}

\author{
Hazwan Bin Zubir ${ }^{1}$, Asiah Abdul Rahim²) \\ ${ }^{1}$ Master Architecture, Department of Architecture, Kulliyyah of Architecture \& Environmental Design, \\ International Islamic University Malaysia, Kuala Lumpur, Malaysia \\ 2) Professor in Architecture, Department of Architecture, Kulliyyah of Architecture \& Environmental Design, \\ International Islamic University Malaysia, Kuala Lumpur, Malaysia
}

Manuscript received: July 04, 2021

Manuscript revised: August 17, 2021

Manuscript accepted: August 31, 2021

Date of publication: August 31, 2021

Corresponding author: Name

Hazwan Bin Zubir

Email

hazwanzubir@gmail.com

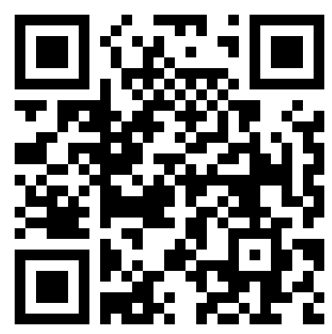

\begin{abstract}
This research is to study the quality of living environment in workers' accommodation for construction workers in Malaysia. In Malaysia, workers' accommodation known as rumah kongsi. The research aim to identify appropriate and quality of living environment for construction workers. Majority the construction workers accommodation in Malaysia are currently in a poor condition. The poor condition of accommodation for construction workers have raised many issues affecting their surroundings and built environment. Some of the issues include health, social and finance. However, there are initiatives made by the Malaysian government especially Construction Industry Development Board (CIDB) and Kuala Lumpur City Hall $(\mathrm{KLCH})$ in which they have come out with guidelines in providing accommodation for the construction workers. Previous studies showed that some developers and contractors providing improper and inadequate living environment for the construction workers, which lead to several issues, including safety and poor living facilities. The objectives of the studies, firstly to study the existing code of practice and guidelines in providing workers accommodation, secondly, to evaluate the existing workers accommodation in Malaysia and finally to propose the good, safety and practical living environment for workers accommodation. The methodology apply in this study include mix method or combine method which are, interview, case study, observation and content analysis. The data obtained from various methods are using descriptive analysis. In conclusion, this research findings attempts to provide guidelines and model of the most suitable living environment for workers accommodation in construction industry in Malaysia.
\end{abstract}

Keywords: Workers' Accommodation in Construction Industry, Living Environment, Construction Workers, Quality Living Environment, Code of Practice.

\section{INTRODUCTION}

The workers' accommodation throughout the years have become main issues in the construction industry. Many sectors have indicated many problems that affecting the temporary workers' accommodation, among other things related to poor accommodation, infrastructure and other facilities 
that affected the surroundings. Due to that poor condition and other matters related to health such as dengue, social and finance. The accommodation provided for them are inadequate and improper to the needs of the construction workers. According to Abdul-Aziz (2001), main contractors usually provide workers accommodation (on-site accommodation) for the convenience of site operatives (regardless of whoever engages them) whose homes are too distant for daily commuting. Normally, the main contractors will provide the materials for the construction workers to build their own temporary workers' accommodation. Due to less and inadequate living facilities, the construction workers chose to sleep in an on-going construction buildings. Abdul-Aziz (2001) stated the constructed temporary workers' accommodation, prone to use economical materials and construction method, as the contractors are unpaid in providing the temporary settlement. He added that, this condition leads to various issues that contribute into a many problems especially in terms of the living condition of the construction workers. Other study by Kumar (2013), highlighted that, the living conditions is as bad as the working conditions. It seems like these construction workers are bound to live in slums where sufficient facilities not provided. The environment is entirely insanitary. There are no adequate sanitation systems, toilets, drinking water, electricity and entertainment. As reported by Yee et al. (2017), there are only three toilets provided in a remnant-like timber shelter packed with at least four hundred foreign people that includes female and kids. In relation to health and safety concern of the workers, Wan (2019), has also reported that the kongsi lack of basic amenities such as sewerage system, shower and washing staff is used at the same place, and food is been cooked in the kongsi itself which may lead to fire due to the structure and components made of flammable materials.

A good living environment increases the human development as well as boost the productivity of both in life and works. In support to the statement, $\mathrm{Ng}$ et al. (2007) identify that a human is being of physical existence and the living environment is the space or venue where the life is articulated. Keles (2011) pointed out the most critical factor in an environmental view that contributes in improving or worsening the quality of life without a doubt is accessibility to environmental infrastructure and services. These include water and sanitation systems, solid waste management, drainage, and transportation. According to Fontinelle (2019), the standard of living refers to the amount of prosperity, luxury, products and services available to a certain socio-economic class or geographical region.

The rumah kongsi is a local term for the temporary settlement of the constructions workers in Malaysia, which is often in poor living conditions. The accommodation to house construction workers provided by the developers or contractors are not adequate, to meet the number of workers who stayed there that lead to overcrowding of occupants. Due to this issue, Department of Standard Malaysia has published MS 2593:2015 Temporary Construction Site Workers' Amenities and Accommodation used by industry players in providing good temporary workers' accommodation for the country. According to the Malaysian Standard of Temporary Construction Site Workers' Amenities and Accommodation code of practice MS 2593:2015, there are four (4) sections; Section 1: Scope and General, Section 2: Planning for Temporary Workers' Amenities and Accommodation, Section 3: Specification for Temporary Workers' Amenities and Accommodation and lastly Section 4: Management and Maintenance for Temporary Workers' Amenities and Accommodation. Thus, this research aim to provide an awareness not only to the authority but also to the employers and contractors on the importance of providing a quality living environment to the labour force within the construction industry. The industry players should comply strictly, when providing temporary workers' accommodation to follow MS 2593:2015 Temporary Construction Site Workers' Amenities and Accommodation and other guidelines to make sure the quality provided for the workers complied.

\section{MethodologY}

\section{A. Methodology Contents}

The methodology applied in this research using mix method which combining interview, case study, observation and content analysis. As mentioned by Brannen (2018), mixed methods means adopting a research strategy employing more than one type of research method. The data obtained from various methods are analysed using descriptive analysis. The interview conducted using two methods, which are, semi-structured interview with government officers from CIDB and KLCH and unstructured interview with the construction workers. From the interviews conducted with the government agency, 
two locals' temporary construction workers' accommodation selected as a case study. Both of the case study were a pilot project of temporary construction workers' accommodation initiated by CIDB and KLCH respectively. The first case study is Centralised Labour Quarters (CLQ) located at Subang, Selangor. While the second case study is at a high-rise construction project at Bangsar South, Selangor. On site-observation of the temporary workers' accommodation also conducted at Port Dickson, Negeri Sembilan. Furthermore, content analysis method used to study the guidelines and example of temporary construction workers' accommodation in other countries.

Table 1: Combine research details

\begin{tabular}{|l|l|l|}
\hline \multicolumn{1}{|c|}{ Research Objective } & Research Methodology & \multicolumn{1}{c|}{ Expected Outcome } \\
\hline $\begin{array}{l}\text { 1. To study the existing code of practice } \\
\text { MS 2593:2015 Temporary Construction } \\
\text { Accommodation and other guidelines }\end{array}$ & $\begin{array}{l}\text { Literature Review } \\
\text { Interview } \\
\text { Secondary Data }\end{array}$ & $\begin{array}{l}\text { Industry players should follow the } \\
\text { standards and guidelines in providing } \\
\text { temporary workers' accommodation. }\end{array}$ \\
$\begin{array}{l}\text { 2. To evaluate the existing temporary } \\
\text { workers accommodation and the } \\
\text { quality of living environment for the } \\
\text { construction workers in Malaysia. }\end{array}$ & $\begin{array}{l}\text { Case Study } \\
\text { Observation }\end{array}$ & $\begin{array}{l}\text { Acknowledge the level of satisfaction of } \\
\text { the current living condition of the 3 case } \\
\text { study of the construction workers } \\
\text { accommodation. }\end{array}$ \\
$\begin{array}{l}\text { 3. To propose the good, safety and } \\
\text { practical living environment for } \\
\text { workers accommodation }\end{array}$ & $\begin{array}{l}\text { Observation } \\
\text { Interview } \\
\text { method in enhancing the living } \\
\text { condition of the temporary workers' } \\
\text { accommodation. Preferable to follow } \\
\text { the standards, guidelines and using IBS. }\end{array}$ \\
\hline
\end{tabular}

\section{RESULTS AND DISCUSSION}

\section{A. Semi-structured Interview}

The interview conducted with two government officers from CIDB and KLCH to collect information on MS2593:2015 and issues regarding temporary construction workers' accommodation in Malaysia. Both of the officers are directly involved pertaining to the guidelines in providing temporary construction workers' accommodation.

Based on the conducted interviews with officers from CIDB and $\mathrm{KLCH}$, they are aware of Malaysia Standard MS2593:2015 as the code of practice in providing Temporary Construction Site Workers' Amenities and Accommodation. The Malaysian Standard is a voluntary action by the employers to provide an accommodation to the workers. Due to that, both parties give remarks on employers taking lightly in their responsibilities to provide adequate workers' accommodation. In overcoming the issue, both government bodies have documented their respective guidelines in providing temporary construction workers' accommodation, which are Guidelines for Temporary Construction Workers' Amenities and Accommodation from CIDB and Garis Panduan Asrama Sementara Pekerja Dalam Bangunan Bertingkat Di Tapak Binaan from KLCH.

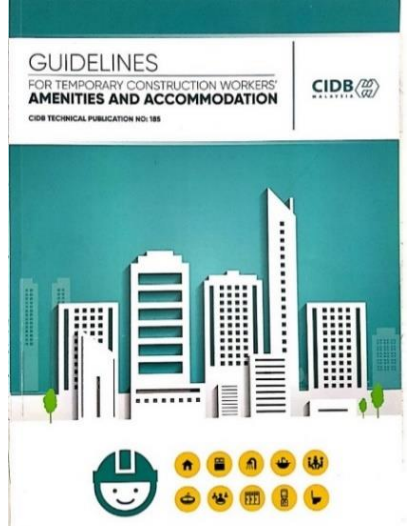

(a) Guidelines from CIDB

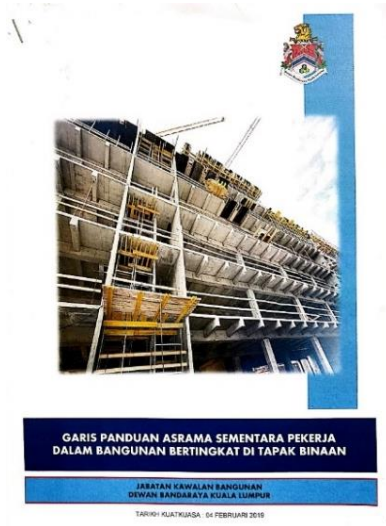

(b) Guidelines from $\mathrm{KLCH}$

Fig. 1 (a) \& (b). : Guidelines provided by CIDB and KLCH in providing temporary construction workers' accommodation

(Source: CIDB and KLCH) 
The Guidelines for Temporary Construction Workers' Amenities and Accommodation (2018), consist of five (5) main sections and twelve (12) components of specification of temporary construction workers amenities' and accommodation. The guideline serves as a basic reference to assist contractors, owners and the operators of the workers' amenities and accommodation to comply with the Malaysian Standard MS 2593:2015 and regulations and local regulatory authorities act.

Whereas in Garis Panduan Asrama Sementara Pekerja Dalam Bangunan Bertingkat Di Tapak Binaan, there are seven (7) main scope and eight (8) basic facilities that need to be provided. The guideline is applicable to a high-rise construction building of more than 6 levels specifically for construction site that has limited site size.

\section{B. Unstructured Interview}

The unstructured interview conducted during the on-site observation at one of the construction project. Due to the limitation of research, the interview conducted with two different nationality construction workers, which are from Bangladesh and Indonesia as they were the only workers presence at that time. In comparison to the answers given by both of the workers, it can be concluded that, the Bangladeshi does not really care much on the quality of their living environment as long as there are a place for them to rest and facilities for them to cook and to clean up themselves. The lifestyle at the temporary construction workers' accommodation seemed to be similar with their culture back at their hometown, which makes them do not give any much of a complaint. As for the Indonesians, they care of having a place to rest and facilities as well as the quality of it. They are quite concerned with the condition of the living environment in the temporary workers accommodation that they lived, in order to be more productive in the construction project.

\section{Case Study}

Two different location of temporary construction workers' accommodation are taken as the cases studies. The two case studies is chosen as it is to show the best example of temporary construction workers' accommodation for outside of the construction site and inside of the construction site. Both of the case studies complies with the guidelines in providing temporary construction workers' accommodation as it is a pilot project launch by CIDB and KLCH.

The first case study is a pilot project initiated by CIDB under the supervision of Construction Labour Exchange Centre Berhad (CLAB) which is Centralised Labour Quarters (CLQ). The building is located at Jalan Sungai Buloh, Subang, Shah Alam, Selangor. CLQ is located outside of the construction site and rented to employer that could not afford to provide and accommodation for their workers.

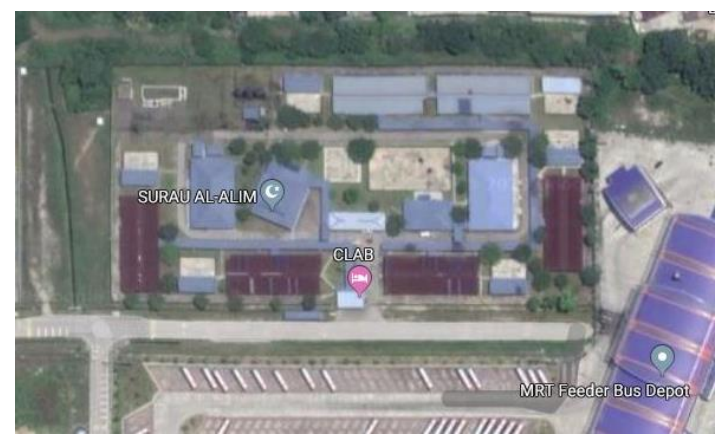

(a) Master Plan

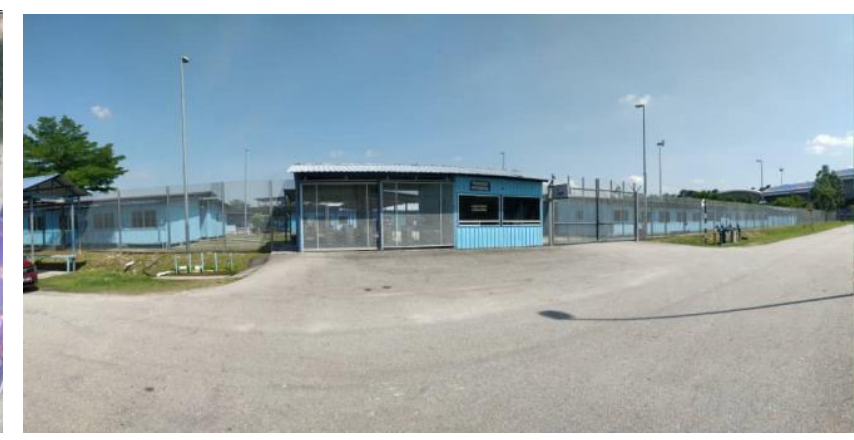

(b) Front view

Fig.2 (a) \& (b) : The master plan and front view of the Centralised Labour Quarters

The CLQ designed with a gated-and-guarded accommodation complete with modern amenities (access card system) for their safety and comfort. Each room at the CLQ can accommodate up to six people and come equipped with double-deck beds, lockers, plug point, wall fans and covered drying area. Facilities such as kitchen, washing area, bathroom, laundry service, cafeteria, convenience store or kiosk, training room, sport facilities, assembly area and surau are present. This will lead to the healthy and active community through social and recreational activities for the workers. 
The second case study is a pilot project initiated by KLCH located inside a high-rise construction project at Bangsar South, Selangor. According to the Garis Panduan Asrama Sementara Pekerja Dalam Bangunan Bertingkat Di Tapak Binaan, the temporary construction workers' accommodation allocate at the ground floor until level two.

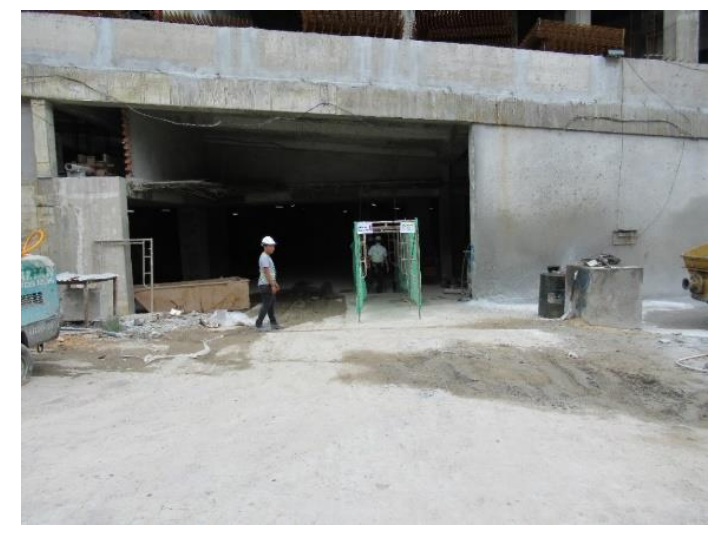

(a) Entrance

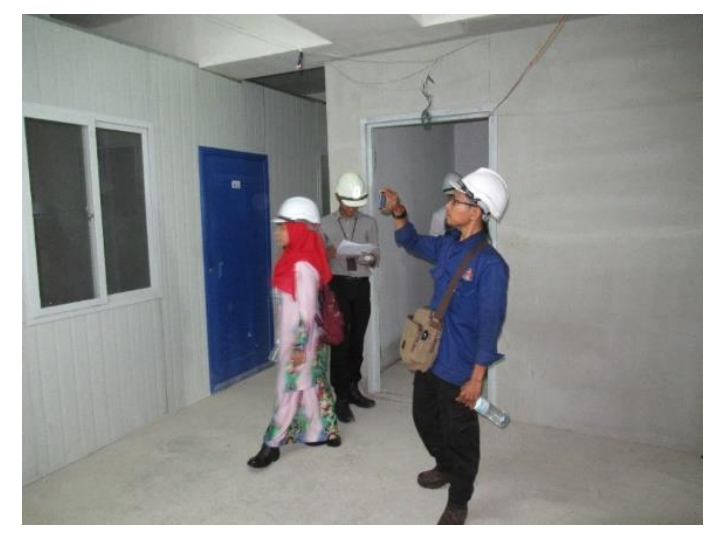

(b) Exterior view

Fig. 3 (a) \& (b).: The entrance and exterior view of the bedroom for the construction workers

(Source: KLCH)

The temporary workers' accommodation is located inside the construction building. The accommodation for the construction workers provided in a form of cabin, which can accommodate up to six people. The room is equipped with double-deck beds, personal lockers and plug point. Other facilities are also provided such as kitchen, dining area, washing area, bathroom, drying area and surau.

\section{Observation}

On-site observation was conducted at one of the construction project to evaluate the common type of temporary construction workers' accommodation provided by the contractor. In overview, the quality of temporary workers' accommodation provided by the contractor at one of construction site is poor compared to the one provided by the government agencies. The differences identified based on the location, lacking of facilities, materials used, the condition of the accommodation and cleanliness of the bathroom and sanitary facilities. This shows that the contractor take very lightly on the welfare and living condition of the foreign construction workers.

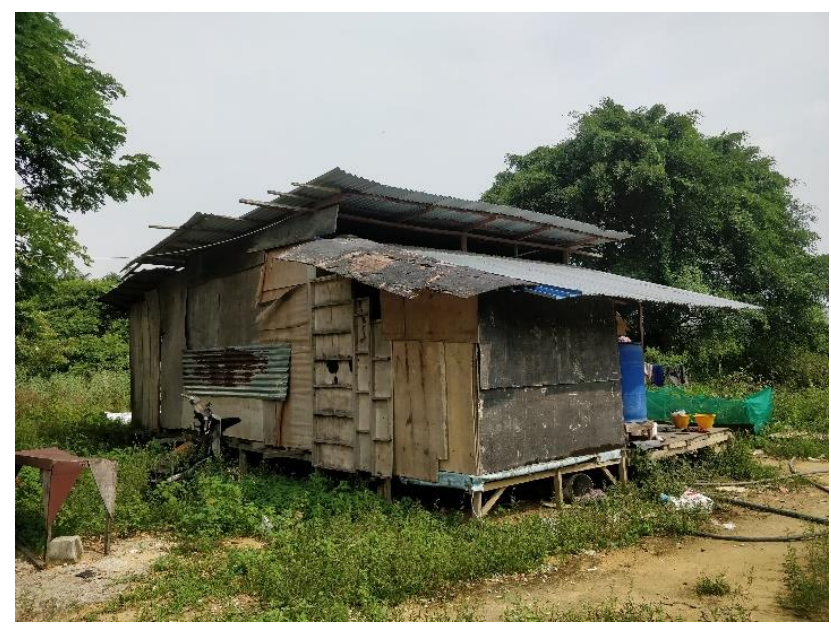

Fig.4. Exterior view of the on-site temporary workers' accommodation with poor condition

\section{E. Content Analysis}

Selected overseas countries taken as case studies, which are Singapore, United Arab Emirates, Australia and United Kingdom. The studies will be analyzing on the guidelines, type of workers' accommodation if any, standards and minimum requirements and example of images of the temporary 
construction workers' accommodation of the country. Based on the findings on the requirements and example of temporary workers' accommodation at Singapore, United Arab Emirates, Australia and United Kingdom, there are similarities and differences between the countries and Malaysia. The result shown in Table 2.

Table 2: Comparison of temporary construction workers' accommodation provided between Malaysia and other countries

\begin{tabular}{|c|c|c|c|c|c|}
\hline Criteria & Malaysia & Singapore & $\begin{array}{c}\text { United Arab } \\
\text { Emirates }\end{array}$ & Australia & $\begin{array}{c}\text { United } \\
\text { Kingdom }\end{array}$ \\
\hline $\begin{array}{l}\text { Type of } \\
\text { building/mat } \\
\text { erial }\end{array}$ & $\begin{array}{l}\text { Cabin } \\
\text { (Metal } \\
\text { Deck) }\end{array}$ & $\begin{array}{c}\text { Cabin } \\
\text { (Metal Deck) }\end{array}$ & $\begin{array}{c}\text { House } \\
\text { (Concrete/ } \\
\text { Brick) }\end{array}$ & $\begin{array}{c}\text { Cabin } \\
\text { (Metal Deck) }\end{array}$ & $\begin{array}{c}\text { Cabin } \\
\text { (Metal Deck) }\end{array}$ \\
\hline $\begin{array}{l}\text { Type of } \\
\text { accommodat } \\
\text { ion }\end{array}$ & $\begin{array}{l}\text { CIDB: } \\
\text { Centralised } \\
\text { Labour } \\
\text { Quarters } \\
\text { (CLQ) }\end{array}$ & $\begin{array}{l}\text { Purpose-Built } \\
\text { Dormitories (PBD), } \\
\text { Factory-Converted } \\
\text { Dormitories (FCD), } \\
\text { Construction } \\
\text { Temporary Quarters } \\
\text { (CTQ),Temporary } \\
\text { Occupation License } \\
\text { Quarters (TOLQ) } \\
\text { Quarters, Housing and } \\
\text { Development Board } \\
\text { (HDB) flats, Private } \\
\text { Residential Premises } \\
\text { (PRP) }\end{array}$ & Not specified & Not specified & Not specified \\
\hline Height & $1-4$ storeys & Multi-storeys & Multi-storeys & Single storey & $1-2$ storeys \\
\hline
\end{tabular}

Malaysia, Singapore, Australia and United Kingdom provide cabin type of temporary construction workers' accommodation. Whereas United Arab Emirates provide house type of building. Furthermore, only Malaysia and Singapore specify the type of accommodation that they provide for the construction workers. CIDB provide one type temporary construction workers' accommodation which is CLQ while Ministry of Manpower Singapore listed six (6) types of accommodation which are PBD, FCD, CTQ, TOLQ HDB and PRP. Most of the height of the temporary construction workers' accommodation is more than single storeys.

In Malaysia, MS 2593:2015 is use as the basis for employers to provide temporary workers' accommodation. As for Singapore, the guidelines varies accordance to the government agencies such as Urban Redevelopment Authority (2020), Singapore Civil Defense Force (SCDF), National Environment Agency (NEA) and others. In United Arab Emirates, the Ministrial Decree No.212 of 2014 on Approval of the General Standards Guideline of Labour Accommodation is use by the employers to provide the workers' housing. Work Health and Safety Act (Code of Practice Managing the Work Environment and Facilities 2011) provide the general guidelines in Australia. While in United Kingdom, the Workers' Accommodation Processes and Standards 2009 provided by International Finance Corporation (IFC) and European Bank for Reconstruction and Development (EBRD) used as the guideline in providing temporary workers' accommodation.

The similarities and differences of the guidelines in providing temporary workers' accommodation between Malaysia and other countries are show based on 17 criteria. The 17 criteria extracted from MS 2593:2015. As supported by Khamis et al. (2017), there are 17 variables in MS 2593:2015 which cover the entirely of construction workers' accommodation and facility's segments. Centralised Labour Quarters (CLQ) provided by CLAB taken as an example for temporary workers' accommodation in Malaysia since the accommodation complies with MS 2953:2015 and guidelines provided by CIDB. Purpose-Built Dormitories (PBD) used as a case study for Singapore. Since there are no specific type of workers accommodation from UAE, Australia and United Kingdom, their guidelines will be in comparison with CLQ and PBD. The result shown in Table 3. 
Table 3: Analysis of criteria in providing temporary construction workers' accommodation between Malaysia and other countries

\begin{tabular}{|c|c|c|c|c|c|}
\hline Criteria & $\begin{array}{l}\text { Centralised } \\
\text { Labour } \\
\text { Quarters } \\
\text { (CLQ) - } \\
\text { MS } \\
\text { 2593:2015 } \\
\text { (Malaysia) }\end{array}$ & $\begin{array}{c}\text { Purpose- } \\
\text { Built } \\
\text { Dormitories } \\
\text { (PBD) - } \\
\text { SCDF, NEA, } \\
\text { URA } \\
\text { (Singapore) }\end{array}$ & $\begin{array}{c}\text { Ministrial Decree } \\
\text { No.212 of } 2014 \text { on } \\
\text { Approval of the } \\
\text { General Standards } \\
\text { Guideline of Labour } \\
\text { Accommodation } \\
\text { (United Arab } \\
\text { Emirates) }\end{array}$ & $\begin{array}{l}\text { Work Health and } \\
\text { Safety Act (Code of } \\
\text { Practice Managing } \\
\text { the Work } \\
\text { Environment and } \\
\text { Facilities 2011 } \\
\text { (Australia) }\end{array}$ & $\begin{array}{c}\text { Workers' } \\
\text { Accommodation } \\
\text { Processes and } \\
\text { Standards 2009 } \\
\text { (IFC and } \\
\text { EBRD) }\end{array}$ \\
\hline Bedroom/dormitory & $\checkmark$ & $\checkmark$ & $\checkmark$ & $\checkmark$ & $\checkmark$ \\
\hline Personal Locker & $\checkmark$ & $\checkmark$ & $\checkmark$ & $\checkmark$ & $\checkmark$ \\
\hline Bathroom/Sanitary Facilities & $\checkmark$ & $\checkmark$ & $\checkmark$ & $\checkmark$ & $\checkmark$ \\
\hline Toilet Facilities & $\checkmark$ & $\checkmark$ & $\checkmark$ & $\checkmark$ & $\checkmark$ \\
\hline Lighting and Ventilation & $\checkmark$ & $\checkmark$ & $\checkmark$ & $\checkmark$ & $\checkmark$ \\
\hline Cooking Area & $\checkmark$ & $\checkmark$ & $\checkmark$ & $\checkmark$ & $\checkmark$ \\
\hline Dining Area & $\checkmark$ & $\checkmark$ & $\checkmark$ & $\checkmark$ & $\checkmark$ \\
\hline Water & $\checkmark$ & $\checkmark$ & $\checkmark$ & $\checkmark$ & $\checkmark$ \\
\hline Electricity & $\checkmark$ & $\checkmark$ & $\checkmark$ & $\checkmark$ & $\checkmark$ \\
\hline Sullage Discharge & $\checkmark$ & $\checkmark$ & $\checkmark$ & $\checkmark$ & $\mathbf{X}$ \\
\hline Sewage Disposal & $\checkmark$ & $\checkmark$ & $\checkmark$ & $\checkmark$ & $\checkmark$ \\
\hline Solid Waste & $\checkmark$ & $\checkmark$ & $\checkmark$ & $\checkmark$ & $\checkmark$ \\
\hline Drainage & $\checkmark$ & $\checkmark$ & $\checkmark$ & $\checkmark$ & $\checkmark$ \\
\hline $\begin{array}{l}\text { First Aid and Medical } \\
\text { Facilities }\end{array}$ & $\checkmark$ & $\checkmark$ & $\checkmark$ & $\mathbf{X}$ & $\checkmark$ \\
\hline $\begin{array}{l}\text { Fire Safety, Protection and } \\
\text { Evacuation }\end{array}$ & $\checkmark$ & $\checkmark$ & $\checkmark$ & $\mathbf{X}$ & $\mathbf{X}$ \\
\hline Signage & $\checkmark$ & $\checkmark$ & $\checkmark$ & $\mathbf{X}$ & $\mathbf{X}$ \\
\hline Leisure and Social Facilities & $\checkmark$ & $\checkmark$ & $\mathbf{X}$ & $\mathbf{X}$ & $\mathbf{X}$ \\
\hline
\end{tabular}

Note: $\sqrt{ }$ : Specified in the document

$\mathrm{X}$ : Not specified in the document

\section{CONClusion}

In conclusion, this research findings attempts to provide guidelines and model of the most suitable living environment for workers accommodation in construction industry in Malaysia. All contractors and developers should comply with the MS 2593:2015 Temporary Construction Site Workers' Amenities and Accommodation. Local authorities should make it as a mandatory for the developers to comply with the guidelines and should take action to those that are against the rules. Professional industry players should play an important role to monitor developers and contractors to follow the act and regulations that have been lay out by the government bodies. The construction workers also play a part in ensuring the safety and cleanliness of the accommodation provided by the contractors or developers. As mentioned under section 19 of the Occupational Safety and Health Act 1994, Employers would be charged and taken into action, failure in providing a safety and health policy to their employees. Based on comparing the guidelines of workers' accommodation in construction industry with four other countries (Singapore, United Arab Emirates, Australia and Europe), Malaysia is at par with many countries. Having good guidelines and standards, with strong implementation enforcement, we can achieve better quality living environment for temporary construction workers' accommodation in Malaysia.

The findings from the first case study show that the facilities and amenities provided in Centralised Labour Quarters (CLQ) is very satisfactory. However, the facilities provided in the second case study, the temporary workers' accommodation provided by $\mathrm{KLCH}$ is satisfactory. The findings from observation show that the facilities provided is not satisfactory for on-site temporary workers' accommodation. In addition, findings from interview highlighted the attitude of the developers and local authorities should change in order to provide a better living environment and quality facilities for the construction workers.

Based on the observation, there are two main issues on the quality living environment of the temporary workers' accommodation, which are the bedroom and sanitary facilities. As mentioned by Keles (2011), the consequences of people that do not have adequate access to infrastructure and services such as water and sanitation system, health issues will arise consequently. Thus, the quality of the 
accommodation need to be frequently supervised and maintained and the accommodation must be in a form of cabin using metal deck. As for Sanitation, the level of hygiene at the temporary workers' accommodation is important, because if the quality of the hygiene is bad, the construction workers have the tendency to fall sick, which will reduce the productivity of their works. Thus, a proper sanitation and water supply needed in order to maintain the level of hygiene in an appropriate manner.

In overall, the Malaysian government are aware and acknowledge having good guidelines and standards and application of Industrialised Building System (IBS) in construction technology will speed up the construction of workers' accommodation. Thus, all players in the construction industry should abide to the act and guidelines provided by the government to ensure the future welfare and quality of living environment of the construction workers is at the highest quality.

\section{REFERENCES}

Abdul-Aziz, A. R. (2001). Foreign workers and labour segmentation in Malaysia's construction industry. Construction Management and Economics, 19(8), 789-798.

Brannen, J. (2018). NCRM Methods Review Papers, NCRM/O05. Mixed Methods Research: A discussion paper [Working Paper]. Unpublished. http://eprints.ncrm.ac.uk/89/

Centralised Labour Quarters (CLQ). clab. (n.d.). https://www.clab.com.my/copy-of-clab-transit-centre-1

Construction Industry Development Board (2018). Guidelines for Temporary Construction Workers' Amenities and Accommodation. Kuala Lumpur: Construction Industry Development Board Malaysia.

Department of Malaysia Standard, Temporary construction site workers' amenities and accommodation - Code of practice MS 2593:2015. Malaysia: Department of Standards Malaysia, (2015)

Department of Occupational Safety and Health. Act 514: Occupational Safety and Health Act 1994

Fontinelle, A. (2020). Standard of Living vs. Quality of Life: What's the Difference? Investopedia. Retrieved 23 August 2020, from https://www.investopedia.com/articles/financial-theory/08/standard-of-living-qualityof-life.asp

International Finance Corporation and European Bank for Reconstruction and European Bank for Reconstruction and Development. (2009). Workers' accommodation : processes and standards: A guidance note by IFC and the EBRD. European Bank for Reconstruction and Development and International Finance Corporation.

Keles, R. (2012). The Quality of Life and the Environment. Procedia - Social and Behavioral Sciences, 35, 2332. https://doi.org/10.1016/j.sbspro.2012.02.059

Kuala Lumpur City Hall (2019). Garis Panduan Asrama Sementara Pekerja Dalam Bangunan Bertingkat Di Tapak Binaan

Khamis, N., Suratkon, A., Mohammad, H., \& Yaman, S. K. (2017). A Qualitative Comparison on Guidelines for Construction Workers Accommodation and Facility. MATEC Web of Conferences, 103, 03010. https://doi.org/10.1051/matecconf/201710303010

Kumar, D. M. (2013). Inimitable Issues of Construction Workers: Case Study. British Journal of Economics, Finance and Management Sciences, 7(2), 42-53.

Ministry of Manpower (2020, Septmeber 7). Various types of housing and their requirements. Retrieved from https://www.mom.gov.sg/passes-and-permits/work-permit-for-foreign-worker/housing/various-types-ofhousing

Ng, S. L., Zhang, Y., Ng, K. H., Wong, H., \& Lee, J. W. Y. (2018). Living environment and quality of life in Hong Kong. Asian Geographer, 35(1), 35-51.

Safety, F., \& Force, D. (2008). Fire Safety Requirements for Temporary Workers' Quarters in Uncompleted Permanent Buildings on. (16), 1-8.

Safe Work Australia. (2011). Managing the work environment and facilities: Code of Practice. Safe Work Australia.

United Arab Emirates Government Portal (2020, September 7) Labour Accommodation. Retrieved from https://u.ae/en/information-and- 
services/jobs/labouraccommodation\#: :text=Establishments\%20with\%2050\%20or\%20more,3\%20sq uare $\% 20$ metres $\% 20$ of $\% 20$ space.

Urban Redevelopment Authority (2020) Guidelines on Temporary Workers' Dormitory. Retrieved from https://www.ura.gov.sg/Corporate/Guidelines/Development-Control/NonResidential/B1/AllowableUses\#CCC

Wan N H W A. (2019). "Rumah Kongsi Perangkap Maut”. BH online 1-7. Retrieved from https://www.bharian.com.my/berita/nasional/2019/08/598097/rumah-kongsi-perangkap-maut

Yee, I. A. N., Lee, L. I. M. M. A. Y., Chow, S., \& Reddy, S. (2017). Inside the dirty, dangerous world of Malaysia's 'kongsi'. The Star Online, 9-11. Retrieved from https://www.thestar.com.my/news/nation/2017/11/27/thedark-world-of-kongsi-rage-goes-inside-the-dirty-dangerous-ghettos-where-construction-workers-are/ 